An Obstacle to Overcome:

Problematic Issues Concerning Early

Childhood Film and Media Education

in Poland.

The New Horizons Association Model

as a Solution

Film and media education in the case of preschool-age children ${ }^{1}$ is a particularly complicated matter. There are many different factors at play, including the question of methodology. Some of the challenges stem from the learning abilities and skills of young children, while others are a result of the medium's inherent characteristics or misunderstandings about the role movies should play in children's cognitive and emotional development. Programmes/institutions dealing with early childhood film and media education should not only focus on children but also address their parents.

In this paper I will discuss some problems related to the audiovisual education of preschool children, focusing on the functioning of Polish institutions working in the field, most notably the New Horizons Association.

\title{
Wider Perspective
}

Education occupies an important place in EU policies. One of the main aims of the Lisbon Strategy adopted in 2000 during the European Council meeting was to adjust educational standards to new social requirements as well as to make it respond to the challenges posed by globalisation. What is more, a lot of attention was paid to preschool education, as Marta Kotarba-Kańczugowska recounts, and problems relating to education in general were prioritised (2011, p. 74). Although film education was not mentioned directly, it appears crucial in helping to achieve the goals laid out in The Lisbon Strategy. In 2010 new arrangements were

1 I will mainly refer to children aged 3 to 7. 
announced. This time, the European directives emphasised the need to increase innovation and creativity at all levels of education. It would seem that including film and media in the educational framework could provide a solution to such expectations. Although in Poland audiovisual education is not separate from the school curriculum, many governmental and non-governmental institutions, organisations and associations have joined forces in order to introduce film and media into primary and secondary educational programmes. Much has been done to improve the situation since the publication of the National Broadcasting Council's (KRRiT, Krajowa Rada Radiofonii i Telewizji) report in 2000, which stated that the role of film and media education in Poland was constantly belittled and marginalised, and pointed to chaos in decision making, lack of modern patterns and appropriate tools for audiovisual education (Godzic et al., 2000). ${ }^{2}$ However, this is not the case with preschool education which remains disorganised and improperly supervised. As Kotarba-Kańczugowska writes:

Nowadays, in Poland, we see a huge diversification of educational approaches in preschool settings. In the public debate various categories are used to define priorities for this group - play, knowledge, discipline, freedom. However, there is a noticeable lack of coherence not only at a national level but also at regional and departmental levels. The same goes for individual initiatives and approaches (Kotarba-Kańczugowska, 2011, p. 82).

Furthermore, the EU document from 2010 states that access to universal and equal preschool education is one of the most important challenges. This is highly problematic in Poland. The number of 4-year-olds attending nursery school/day care centres is strikingly low, as it is not compulsory and often considered a last resort (when no family members are able to take care of the child), rather than a form of education and socialisation. In 2008, on average, $90 \%$ of children aged 4 attended day care centres in Europe, while the number is not more than $50 \%$ in Poland, even though a slow but steady growth in numbers can be observed (Kotarba-Kańczugowska, 2011, p. 77). ${ }^{3}$ Another problem is the insufficient number of day care centres particularly in the countryside and in smaller towns. One of the solutions to this is the recent creation of the so-called "alternative forms of preschool education". Day care centres are public, private, or supported by associations with particular philosophical or religious affiliations. To sum up, early childhood education in Poland remains a privilege, and film education at that level of development is a rarity (Men.gov.pl, 2016)..$^{4}$ In other parts of Europe the situation is different, due to the emphasis placed on a variety of forms of education.

2 The document entitled Raport o stanie edukacji medialnej $w$ Polsce [A Report on the State of Media Education in Poland] was prepared by a group of scholars from the Jagiellonian University, chaired by Professor Wiesław Godzic.

3 Data according to EUROSTAT (Kotarba-Kańczugowska, 2011, p. 77).

4 The website of the Ministry of National Education reads: "The priority of the government in the area of education is to increase access to high quality education, for example by promoting preschool attendance in the case of children aged 3-6 years old, as well as increasing access to this form of education in rural areas". These declarations, however, are still at great odds with reality. 


\section{Things That Can Be Done to Address the Problem}

Perhaps, however, there is no need to introduce film education in day care centres/preschools while at the same time following European standards and adjust to EU strategies of development. In other words, why should young children be exposed to film and media education? What kind of additional obstacles must be overcome, except the general ones indicated above? What makes film and media education specific, unique and exceptional at this stage of children's development? Why is it almost completely absent at the level of early childhood education?

Firstly, we must note that film and media are multi-layered forms of art, and as such they might cause certain perceptive difficulties. However, they stimulate the senses and do not require traditional knowledge (the ability to read or write) in order to convey their messages. Even very young children are highly responsive to those forms of art, as from the early stages of development they process the world mainly through sight and sound, are capable of abstract thinking, and are prone to operate more on an emotional than a cognitive level. Compared to other forms of art and means of communication (literature, music and fine arts) film and media offer a broader palette to influence children's sensibility. This variety of stimuli can act in a more effective and efficient way, if applied in reasonable doses. Thus, one of the most important aims of film and media education is to stimulate the communicative sensibility and imagination of children.

Secondly, taking children to the cinema can become a special event. Cinema going establishes receptive habits, children become familiarised with art, and the silence and darkness can imbue the experience with special meaning, a part of life to be treasured.

Thirdly, a crucial factor to be taken into account is the interdisciplinary nature of audiovisual culture education. It is worth introducing children to film and media education as early as possible because it can support other forms of education, and, specifically, because it can support incoherent forms of art through its multilayered character. In other words, since it complements fine arts, music, theatre (and other performing arts), film and media education may easily be introduced into day care centres/preschools, sustaining already existing forms of education.

Last but not least, audiovisual culture, from my point of view, is essential for early childhood education because the development of technology and means of communication makes it more and more omnipresent, while at the same time more and more accessible. Children have to deal with audiovisual texts very early on in their lives and these are nearly impossible to avoid as they permeate public space (streets, squares, different kinds of institutions and even public transport is full of audiovisuals spots, advertisements and so on).

The report titled Children and Parents: Media Use and Attitude states that ownership and access to devices providing audiovisual texts such as tablets has recently increased across all age groups. Smartphone ownership has remained at the same 
level, while television and game console usage have declined (Ofcom.org.uk, 2014, p. 4). Furthermore, all electronic devices are now constructed in such a way that they can be used intuitively (most often they are touch sensitive), and even very small children are able to operate them, so they affect them at the earliest stages of psychological and mental development. If there is no way to avoid audiovisual culture in everyday life, it seems to make sense to teach children how to make a correct use of them. From that perspective, film and media education appear as a necessity rather than a possibility.

Audiovisual literacy is a must in a globalised world, but as the authors of standards for film and theatre education conclude:

Film and media education should first seek to develop conscious and critical thinking together with movie reception, and only then help children use the tools made available by modern technology in order to help navigate the tangled web of contemporary media. While we know that not every child will become an actor, a playwright, a film director or a scriptwriter, they will all grow up to become actors of everyday and public life, as well as the audience of innumerable film, theatre and media performances (Kosiński, Katafiasz, Marszałek, 2008, p. 16).

A comparison and close examination of the advantages and disadvantages of audiovisual education leads to the conclusion that the benefits far outweigh any disadvantages. In fact, renouncing and negating the necessity for audiovisual education can have harmful consequences, ones that are possibly worse than the potentially negative influence of film and media on the emotional and cognitive development of children.

What are the general problems when introducing film and media into early childhood education? In the early stages of development, children are highly responsive to visual and audio impulses but they are also prone to emotional overreaction. Suspension of disbelief is often their natural operating mode. The likelihood of uncontrolled immersion is high, especially since audiovisual texts can often create the impression of reality, thanks to their technical and technological capacities. Moreover, children need to be carefully supervised, possibly for long periods of time, when interacting with audiovisual texts of culture (especially feature forms), as they are often unable to distinguish between fact and fiction, what is imaginary and what is real. However, there are other obstacles when considering children and audiovisual education. One of them is that small children lack the ability to concentrate for long stretches of time and need constant, new and diverse forms of stimulation. Audiovisual texts, mainly films, are time-based and require not only longer attention span, but also the ability to comprehend cause and effect. Furthermore, children prefer active forms of entertainment, so movement and expression should be involved in the process. Traditional film viewing patterns do not provide optimal circumstances for a proper audiovisual experience. Dark, enclosed spaces, forced immobility, minimal level of interaction, and keeping silent 
are required elements of participation which create challenges for the scope of audiovisual education. Yet, if taken into consideration and carefully analysed, these obstacles can be overcome. Children should be taught not only how to experience audiovisual texts, and how to participate in culture, but also about the ways these texts are made. For example, if children are allowed to experience and observe the "making of" process, or shown the mechanism of projection, the line between fiction and reality will become clearer for them, and at the same time critical thinking will be activated. As theoretical knowledge at that level of development is more difficult to absorb, teachers can substitute explanations with practical demonstrations, involving interactive forms of education. The distinctions between playing and learning need to be minimised, and that can easily be done through the use of film and media (typically perceived as entertainment).

Because of their complicated structure and technical advancement, film and media raise many concerns and are viewed in a prejudiced manner: they are often considered inappropriate for children's capabilities, distracting and, consequently, harmful. However, in our age of simplified interfaces, film and media can fit children's needs and support their innate biases. Thus, paradoxically, the development of advanced technologies and portable devices in fact supports audiovisual education, as well as other forms of education. However, there are more specific issues to be examined. It is becoming clearer nowadays that children ought to participate in film and media education in order to help them function in a globalised world (bearing in mind the arrangements laid out in the Lisbon Strategy for Europe). Consequently, teachers working with preschoolers should receive additional film and media education related training to improve their qualifications. As recent studies show, preschools/day care centres in Poland no longer suffer from a lack of equipment. Even though so-called "complex media" (DVD players, computers, multimedia projectors) are widely accessible, they remain rarely used in comparison with "simple media" (Huk, 2013, p. 4), ${ }^{5}$ maybe as a result of preschool staff preferences. But even if they eventually become part of the educational process, in the opinion of experts the aims most often achieved by media education are: developing cognitive and educational, as well as emotional and incentive functions; applying information in the form of text, sound, picture, film animation in order to increase the level of perception; creating pro-social attitudes and promoting general humanistic values. The problem with this approach to film and media education is that it does not directly correspond with media specifics and practices as exemplified in early childhood educational settings. Moreover, such goals that are specific to media - the ability of critically interpreting a media message, decoding, understanding and receiving information, and exposing the interactive aspects of communication - are rarely achieved in preschool settings. The reasons for this may lie in insufficient knowledge and skills among early childhood education teachers. Research reveals that this kind of education "has been marginalised", and experts

5 This research was carried out in 2012 across 46 day care centres in Katowice - they are therefore not representative of rural areas where both accessibility to and usage of complex media can be lower. The respondents were experts. 
consider it to be "of little significance, unimportant and even useless at that level of education” (Huk, 2013, pp. 4-5).

\section{Not Only Children}

And yet, is it enough to educate preschool children and their teachers? The point is that even if film and media education were to be institutionally introduced into preschool and other early education settings, we would still only be halfway to success. Who should really be educated? Parents and filmmakers are the groups who would benefit immensely from professional support. The former have regular contact with children and should be able to answer all of their questions. A child can remain curious about the material provided for a longer time than that of a screening or a school lesson. The latter while studying rarely have any training or classes directly dedicated to the issues considering films for children.

But the main issue is changing parental notions about the function of film and media in their children's lives, notions that are very often highly stereotypical. Film, television, and finally the Internet are seen as poison for young people's minds, and a factor negatively affecting their physical well-being. There is no need to quote numerous articles or to provide precise data, most of which leads to the same conclusion: audiovisual culture is modern society's best recognised and most devilish enemy. Not many parents, however, are aware that these studies refer to situations of audiovisual abuse, rather than controlled, supervised and carefully planned exposure. As a consequence, film and media are blamed for delays in speech development, deficits in memory and thought process as well as problems with reading and writing. What troubles parents and opponents of audiovisual culture most is the influence of mass media, e.g. its ability to influence the emotional development of children - resulting in extra sensitivity, negative approach to reality, egotism, lack of empathy, the urge for instant gratification. Moreover, the negative impact on vision and physical development (especially its effect on children's posture) are also mentioned. ${ }^{6}$ Aleksandra Kruszewska remarks about similar negative side-effects. Since they are presented in contrast with the positive effects of the influence of media on children, the disproportion between its advantages and disadvantages can be clearly seen (Kruszewska, 2013).

Not many parents (or teachers) pay attention to the fact that, for example, education through film as well as computer games can improve abilities in storytelling (specifically dramatic composition), role-playing skills, and the ability to identify patterns of cause and effect (i.e. developing logical thinking) along with the development of gross and fine motor skills. The Children and Parent 2014 report confirms these suppositions: "Around a quarter of parents express concern about the media content their child has access to, with concerns about the Internet more

\footnotetext{
${ }^{6}$ A list of such dangers can be found on the website of Council Preschool no. 51 functioning in Cracow.
} 
likely voiced by parents of older children (8-15)" (Ofcom.org.uk, 2014, p. 5). And as a result of those anxieties:

Nine out of ten parents control their child's access to the Internet in some way, with most parents using a combination of approaches including using technical tools, having rules around access and use, regularly talking to the child about specific risks and supervising the child's online activity (Ofcom. org.uk, 2014, p. 5).

Although in this case the report addresses internet usage, earlier issues referred to television and film consumption. At the risk of oversimplifying, I would rather highlight some general tendencies than present specific data. On the one hand, parents view audiovisual media as a threat, but on the other, paradoxically, only and exclusively as a form of entertainment (which is not the case with board games for example) and they often include access to audiovisual media in their parental system of punishments and rewards. In this scenario, supervised access to tablets or TV plays a crucial role. Children can watch films on portable electronic devices or play computer games if they behave properly, even if a parent generally considers the media harmful. There is another interesting aspect related to parental control of the content. It is mainly based on negative selection, which broadly means that parents do not allow children to watch excessively violent films or play violent video games. But they rarely consciously choose what children should watch a consequence of a lack of film and media education, and even more of a lack of awareness about the positive role that audiovisual culture can play in children's development. In summary, parents are victims of prejudices and stereotypes of two kinds: firstly, those regarding the harmfulness of media; secondly, those related to the uselessness of media in education and their purely entertaining function.

What kind of films do children watch in preschools/day care centres? The answer to this question sheds light on further challenges. Tomasz Huk's research has shown that:

According to experts, the animated films most often watched [if they are watched at all, which is not the case in all preschools - author's note] are Polish cartoons: Bolek i Lolek [Bolek and Lolek, 1963-1986], Miś Uszatek [Floppy Bear, 1975-1977], Reksio [Reksio, 1967-1990]. Next up are the cartoon series Il était une fois... la vie, [Once Upon A Time... Life, 19861989], Il était une fois. . l'homme [Once Upon A Time... Man, 1978-1981], Il etait une fois... les decouvreurs [Once Upon A Time... The Discoverers, 1994] with 37\% of respondents; followed by Disney movies: Winnie the Pooh, The Lion King, 1994, Beauty and the Beast, 1991, Mickey Mouse [? author's note], Cinderella, 1950 with 28\% of respondents. Czech and Slovak cartoons: Kretek [Mole, 1957-1997], O loupežníku Rumcajsovi, [Rumcajs The Robber, 1967-], ...A je to! [1976-2013] - with 15\% of respondents, and others like Bob the Builder [1999-], Rudolph the Red-Nosed Reindeer: The Movie, 1998, and Rudolph the Red-Nosed Reindeer \& the Island of Mis- 


\begin{abstract}
fit Toys, 2001, Opowieści familijne [Family stories? - author's note] which $4 \%$ of respondents mentioned only once. Franklin's Magic Christmas [2001], Kropelka -od kropli do deszczu [A Droplet - From Drop to Rain? - author's note], films about healthy nutrition, Little Red Riding Hood, [? - author's note], Swiat wedtug śmiecia [The world according to garbage? - author's note], Przygody Kangurka Hip Hop [The adventures of Hiphop the Kangaroo - author's note], the Grim Brothers' Fairy tales, Uważaj na drodze [Watch out on the road - author's note], The Seasons: Spring, Summer, Fall, Winter, Clifford [Clifford the Big Red Dog, 2001-2003], Franklin [19972004], Dinozaury [Dinosaurs] and Andersen's fairy tales were animations mentioned only once. Films listed by respondents in this survey are helpful in better understanding the aims of early childhood education because they are deprived of violence, involve a positive message, and teach socially and morally acceptable values and attitudes (Huk, 2013, pp. 5-6). ${ }^{7}$
\end{abstract}

These cartoons certainly have all the above features. However, a short analysis of the list quickly shows their shortcomings. Preschool teachers tend to choose films they were familiar with as children themselves (Polish and Czechoslovakian productions). For them, these films offer a sense of nostalgia and the satisfaction arising from a well-performed duty, as they introduce new generations to the idealised world of their past. But surely Bolek and Lolek or Reksio fail to address the problems of contemporary societies (such as religious or ethnic diversity, etc.) and are hardly relevant in our globalised times. The lack of more recent Polish animated films must also be caused by either a lack of awareness or access issues (production and distribution problems). In this case, there is room for improvement through the education and support of filmmakers.

The second choice of preschool/day care teachers are American classics or the previous seasons' blockbusters. Are they really of educational value, and are they suitable for very young children? Is it possible for 4-5- or even 6-year-old children to spend more than an hour in front of a television screen? Is boxoffice performance a good indicator of quality? Teachers' choices appear to be automatic, rather than based on methodology, awareness or experience. Accessibility, as mentioned earlier, can also play a significant role. Most parents probably show their children similar movies at home, but this time as entertainment. Could Wiesław Godzic's statement about the generation gap, defined in terms of a split between digital children and analogue adults be true (Godzic, Rudzińska,

\footnotetext{
The author of the quoted opinion is not very careful or detailed in his research, as his respondents probably were in their answers. While listing film titles he does not provide us with the original titles or the year of production (I tried to add this data if possible), which causes numerous difficulties. I did not find some of the films on website databases at all (for example Il etait une fois... les decouvreurs - 1994, Opowieści familijne [Family stories]). In many other cases Huk is just not precise. When he refers to Mickey Mouse, we don't know if he wants to indicate the TV series Mickey Mouse and His Friends (1994-1995) or one of the other films with Mickey as protagonist. When he writes about Rozbójnik Rumcajs, I presume he is referring to Przygody rozbójnika Rumcajsa. Despite the fact that, as I have shown, the details are incomplete, Huk's research still allows us to draw some general conclusions.
}

\title{
96
}


Kowalewska, 2015, p. 63)? Will digital children be forced to discover the world of media on their own?

The roots of the problem lie only partially in the parents and teachers' "analogue" mentality. The heart of the matter is in fact situated somewhere else: in the production and distribution of Polish films for children and teenagers. A 2016 report titled Does Cinematography Spin Around Children, describes the condition of this branch of national cinematography as "dramatic" (Grawon-Jaksik, Materska-Samek, 2016, p. 7). In her attempt to "diagnose the patient", Anna Wróblewska writes:

The development of animated film was [before 1989 - author's note] closely related to the institutional system and top-down politics. Paradoxically, the development of cinema for kids was spurred by unique administrative sanctions and the pressure communist authorities imposed on film studios. In order to pursue artistic ambitions, studios were required to fulfil a role in providing educational material addressed at youngsters and available for public release. At the beginning of the 1990s, animation studios, and thus animated films for children lost this institutional support as the liberal economy made its way into culture, painfully weakening, among others, national cinematography (Wróblewska, 2014, p. 152).

The situation went from bad to worse when public television gradually ceased producing and broadcasting Polish animated films, and pursued international bids. The crisis continues, despite the survival of some of the old animation studios, the creation of others, the availability of high quality equipment, a high number of educated professionals and international recognition in the form of industry awards. The data provided by the report paints a very bleak picture. The scale of the crisis is illustrated by these figures: Poland was sixteenth on the European list of producers between 2004-2013, and only six films for children and teenagers were released (two of them are animated), with almost no distribution during that time period (Grawon-Jaksik et al., 2016, p. 25). Discussion of the problem has just begun. The reasons for the collapse of Polish film for children and teenagers are diverse. The report attempts to identify most of them. However, from an educational perspective, the most important factors stem from the fact that films for children are still not considered important enough for filmmakers, are not financially secure for producers, and are economically inefficient (as they are not properly promoted) for distributors. The former group needs education and support in the first place because:

In most situations, when the producer tries to gather basic information about the children's film market, the Polish film director they hire "has not seen a single European movie for kids in the last ten years, not even one", and that is why "they work in a sort of a vacuum" and "have absolutely no idea, no idea whatsoever, what contemporary films for children look like and how they are made in Sweden, Germany, Holland or even in Lithuania 
and Latvia". "As for the producers, something is changing in this respect, especially when it comes to the younger generation". The evaluation of film directors remains, however, desperately unsatisfactory (Grawon-Jaksik et al., 2016, p. 46).

\section{A New Hope - the New Horizons Association}

There are a number of institutions in Poland dealing with the problem of film and media education for children and teenagers. Some day care centres/preschools try to address these challenges, others do not. In this respect very little has been done so far. In the following paragraphs, I will explore the issues facing film education. In Lodz, children can participate in workshops or meetings during which they discuss books and watch cartoons but also make animation or build film sets. Such events are organised by the Se-Ma-For Museum of Animation and the Museum of Cinematography (a series called Little Cinematograph). Let me focus, however, on the activities of the New Horizons Association, based in Wroclaw (Kinonh.pl), ${ }^{8}$ European Capital of Culture in 2016, as it represents the most complex and multifaceted approach to the problem of film in early childhood education.

The extended activities undertaken by the New Horizons Association have directly grown out of the origins of the organisation. The Association was founded by Roman Gutek - a businessman and cultural activist. Gutek studied management and took part in Aleksander Jackiewicz's anthropology seminar at The Institute of Art at PAN (the Polish Academy of Science), and, as one of Poland's first cultural activists, he builds on his logistic and cultural experience to promote openminded thinking about film culture. His approach also allows us to understand just how important it is to educate audiences. Gutek started his career organising film festivals (for example the Warsaw Film Festival) and film clubs, while running his own distribution company, Gutek Film. Later on he turned his attention to the field of education. Nowadays, the New Horizons Association remains a brand mainly associated with arthouse film festivals such as T-mobile New Horizons and the American Film Festival.

However, the Association's ambitions go much further than that. The organisation tries to address the needs of audiences across different generations. Let me elaborate further on projects for the preschool-age group offered by this nongovernmental organisation. Each year the Association organises a film festival (Children's Film Festival) aimed at children aged 5 to 12. It offers ten days of screenings of over 40 films, many of which come from countries such as Norway or France (this year's edition). These countries' cinematographies have dealt with

\footnotetext{
8 Roman Gutek comments on the choice of Wroclaw for the headquarters of the New Horizons Association's activities: "Over 500 Polish films have been produced in Wroclaw; it was once the location of a dynamically developing film culture with several quality studio cinemas. However, in recent years, the city has lacked a theatre showing ambitious Polish or foreign films".
} 
the production of films for children much better than Poland. ${ }^{9}$ The Children's Film Festival is not only responsible for introducing a new repertoire, but also for making films more available as the Festival visits 15 Polish cities (which certainly doesn't address the problem of film culture not reaching rural areas). The festival is accompanied by panel discussions and workshops, and - of particular interest and value for this study - meetings for professionals dealing with education and children's culture (in Wroclaw and Warsaw). Additionally, in 2016, the year Wroclaw was designated European Capital of Culture, the educational project aKino was launched. Monthly meetings were held, revolving around a particular keynote, aimed at groups of children of various ages, including the youngest. In May, for example, issues of identity ("I am myself") were discussed. The project's website lists the following explanation:

What is identity? It is self-awareness. In May, we will create audiovisual portraits. Photos, films, drawings, songs that you sing alone or with a choir or in a duet - all forms are allowed, there are no restrictions. Submitted applications will be turned into a movie - to premiere in September. One selected application will be featured in a mural. Show us who you are!

These workshops are accompanied by a screening of a 3-minute-long Danish animation by Susan Hoffmann. The summary of the film plot states: "The grey lynx does not fit in with its group of peers and their colourful fur. Its attempts at befriending them fail and it is mocked and rejected. The desperate animal finally finds its way into the unfriendly pack's graces" (Kinodzieci.pl). ${ }^{10}$ Both workshops and the film perfectly match the emotional and intellectual capabilities of the youngest children and at the same time are geared to address the challenges of the modern world and the threats raised by globalisation. In addition, at weekends in Wroclaw, children can attend New Horizons Cinema Kids' Mornings. Although these are mainly available to the city's inhabitants, they still provide a solution to one of the problems concerning early childhood education. Through the use of multiple activities, such as screenings and crafts workshops and movement, these meetings stimulate different senses in order to inspire imagination and creativity. Indeed, as the Association's social awareness campaign (supported by a number of celebrities) slogan says, children are on the Horizon (Dzieciakinahoryzoncie.pl).

The New Horizons Association expands its focus to teachers and parents as well, which is not necessarily the case with other institutions or initiatives. In Warsaw's Muranów and Wroclaw's New Horizons cinemas, screenings and psychological-educational workshops and "re-training" courses for preschool teachers have been organised and held for the past 4 years. What is more, a database of films with additional teaching materials is available for download along with a special web browser facilitating the selection of age appropriate films for

9 Every year the number of places the festival visits rises. In 2017, the $3^{\text {rd }}$ edition of Kids Film Festival will be presented in 30 cinemas in 27 cities.

${ }^{10}$ Each year the descriptions, challenges and the whole project is modified but rather in the details than general aims. 
children. Teachers can enroll a group of children or pupils for a series of meetings with the participation of special guests and experts. Pedagogical materials consist of basic paratexts (information about the film and film director, comments from experts, film makers, opinions of psychologists), as well as screenplays for classes and special evaluation sheets. They are useful not only for professional educators but can be easily adapted by parents. Again, however, this project is restricted to urban spaces and operates either in main Polish cities, or in smaller ones where arthouse cinema owners and town cultural institutions have decided to join the project (for example cinema Amok in Gliwice, Community Centre in Kęty, Zagłębie Palace of Culture). It is also not certain that special guests' visits are possible in all cases. Nonetheless, despite several drawbacks, the efforts of the New Horizons of Film Education Association have been honoured with awards such as the Polish Film Institute's award.

These are certainly well-deserved, as the New Horizons Association pays close attention to those aspects of film education that are most often neglected. Their focus seems to be especially directed at parental film education and their awareness of audiovisual culture. The Kids on the Horizon website has a dedicated subpage titled "the Parent Zone", which facilitates communication. From October 2015 to June 2016 workshops for children and parents were offered in Warsaw and Wroclaw. While children participated in after-screening art workshops, their parents had the opportunity to talk with psychologists. The general idea was to prepare adults to talk with children about films. Earlier on, special parent-teacher meetings were organised, providing basic information about different projects, plans, movies, and the way we can work with children at home. This kind of cooperation is helpful for children of all age groups, but it is especially valuable for the youngest children. Furthermore, access to film education in small towns has been supported through the distribution of feature and animated films in recent years for children aged $4-15$ by New Horizons (following in the footsteps of Roman Gutek). All titles are rated, and the browser helps people to find suitable films which can be loaned out not only by the cinema but also libraries, etc.

Last but not least, Films for Kids.Pro is one of the most promising initiatives of the New Horizon Association, dedicated to filmmakers. Education and support for them are provided within the framework of this project. According to the website:

Films For Kids.Pro works with 8 teams (a scriptwriter and producer) on participants' projects. We develop the script from short synopsis to second draft together with learning about production basics (the estimated budget, financing and promotion plan). Among our tutors are Philip Lazebnik (writers' tutor - scriptwriter for Dreamworks movies including Mulan, Pocahontas, currently working in Europe), Kirsten Bonnen Rask (writers' tutor - former script consultant for Lars von Trier and Urlich Seidl, currently a writer, producer and consultant for numerous children's films, head of South Norwegian Filmcentre) and Ronald Kruschak (producers' 
tutor - producer and writer, his films have received numerous awards in Germany, some have reached an audience of 1 million people) (Dzieciakinahoryzoncie.pl).

While this kind of support in Poland is unique, in other parts of Europe it has become standard practice. Workshops and pitchings are necessary to rebuild cinema for children in Poland and strengthen preschool education.

\section{The New Horizons Association - Summary and Critical Approach}

The New Horizons Association projects I have briefly described above, certainly do not solve all the problems of preschool education in Poland. However, this kind of activity seems highly promising, and may be considered as an example of the upcoming more complex, systematic and comprehensive developments in the scope of film education for the youngest children. Still, efficient solutions for preschool education need to be initiated, and run by governmental or council units, starting from the Ministry of Education. In the Journal of Laws (30 of May 2014) presenting decrees on the Core Curriculum for early childhood education, film is mentioned just once. All the official decrees prescribe is that preschool children should know how to behave properly in the cinema (Journal of Laws of 2014, item 803, p. 5), and further on underline the importance of role-playing as a child's fundamental ability, but rather in the context of theatre than cinema. In contrast, other arts (such as painting, sculpture and architecture, music) are widely discussed. The New Horizons Association's preschool film education projects should probably be highly evaluated and considered as fundamental despite its limitations. The projects are an answer to A Framework for Film Education - a document written and created in response to " 12 recommendations made in the research report Screening Literacy, funded by the European Commission, and published in 2012" (p. 3), although they do not sufficiently acknowledge Polish realities in the sphere of film education (which is practically non-existent in Poland).

To summarise, the advantages of the projects I have referred to in the descriptive part of my article, it is worth to emphasize the multi-targeting (involving children, parents, educators and filmmakers), and versatile character of The New Horizons Association activities (they organise festivals, workshops, pitchings, etc). Most importantly, a close analysis of their content shows that they attempt to combine two strategies: studying film and educating through film (Depta, 1975). This kind of approach is rather exceptional. Most educators, even if they theoretically appreciate the role of film in education, in fact focus on the possibilities of film as a methodological tool explored in other fields of education (most often literature) ${ }^{11}$ In the case of preschool education, this kind of attitude is especially irrelevant as

\footnotetext{
${ }^{11}$ A good example of such a reductive and instrumental approach to film can be found in the following article: Projekt edukacji filmowej $w$ ksztattowaniu postaw proekologicznych dzieci $w$ wieku przedszkolnym [Project for Film Education in Shaping Pro-ecological Attitudes Among Preschool Children] prepared by Lidia Suska (Public Kindergarten no. 12, Nowa Sól).
} 
children that age cannot read or write, so it is naturally the best time to develop audiovisual competences which they have already acquired.

And yet, the New Horizons Association activities have their weak points. Firstly, their activity is restricted and addressed mainly at the citizens of big cities such as Warsaw and Wroclaw. If they cooperate with institutions located in smaller towns such as local cinemas, their participation is voluntary, and as a result - random and optional. A map of the New Horizons presence in Poland would be full of black holes. It is not a nationwide, systematic initiative and it reaches only those day care units and institutions of culture which are already actively involved in film education. Organising a project on film education addressed at children who cannot visit big cities would certainly be challenging but nevertheless achievable in the age of electronic devices and the Internet. A film education e-learning project for young children should especially be considered. Preschool children from the countryside are not always able to visit distant cinemas, even if they should, as it causes financial and logistic problems.

Secondly, The New Horizons Association's film education projects need better advertising, and wide communication channels to reach potential participants. Existing websites are difficult to use. There are many of them, which are not properly integrated or clearly linked. This situation is of course related to the number of projects the New Horizons Association runs for various educational levels. Some of them are modified, some of them remain unchanged, others just disappear. For example, two new ones have recently been introduced - "I go to the cinema" (aimed at children aged over four years old, the project encourages regular participation in film culture), and "Film adventures" (which combines film screenings with workshops). On the one hand, from my point of view, it would be helpful to create a web page presenting only projects addressed at preschool children, their educators and parents, and separate them from others. On the other hand, I find it essential to reduce the number of projects, while at the same make their main purpose clearer and more specific. These modifications would improve communication with participants, make it more efficient and comprehensible. Furthermore, the constant changes in programming do not allow the projects to settle in the consciousness of their potential receivers or in the landscape of educational possibilities offered in Poland.

Thirdly, educators and teachers need support and some kind of guidance. Research on how preschool educators see and treat film education and how they are prepared for it, and finally what they consider film education to be about, has not yet been carried out. My assumption is that they should be offered support which is much more complex and methodologically sophisticated than booklets referring to the particular screenings. The New Horizons Association publishes a magazine titled "New Horizons of Education" but, as one of its reviewers notices:

The magazine has not yet defined itself to its readers, because no details about frequency of its circulation have been announced. The same applies 
to its readers. Based on the first three issues of the magazine, one can assume that it will be addressed at academic researchers. But there will be good reason to lament if educators of lower levels are excluded (Smołalski, 2013).

Polish educators of preschool level are in need of and would rather have a kind of textbook (similar to the one published by the British Film Institute Look again! A teaching guide to using film and television with three-to eleven-year-olds, 2003) more than academic discussions. The first paragraph of Look Again! states:

Television and video are among the first cultural experiences of most children in the UK in the $21^{\text {st }}$ century. At an early age they learn to make sense of the flickering images on the screen, the changes of size and angle, the switches of background and character, the sounds and music that signal danger, comedy, excitement and happy endings. By the time they are three years old, most children have learned another language in addition to their spoken mother tongue: they have learned the codes and conventions through which moving images tell stories. Their mastery of this language is still limited: they may not be sure yet about what is "real" and what is "pretend" (although they are very interested in finding out); they may understand little of what they see on the news, daytime films and game shows, or early evening soap operas. But most children will have their own collections of favourite videos, which they know almost by heart, and their eagerness to catch broadcasts of their favourite shows often ensures that they quickly learn to tell the time and operate the video recorder (Look again!, 2003).

As a result, the paragraph immediately signals all the sore points of film and media education in a laconic but decent and communicative way.

Finally, there are elements of the content of the New Horizons Association projects that need more attention and, possibly, remodeling. The disproportion between the number of projects for small children and those devoted to children of different age groups can be easily noticed. A difference is also detectable in the number of films that we can find using the New Horizons browser. The list of those dedicated to the youngest audience is much shorter than any other. But the lack of interest of the New Horizons Association in American cinema, the absence of blockbusters (which belong to the so called mainstream cinema and which have received wide distribution in Poland) on their list of screening suggestions, should be considered significant negligence. What can be seen in the multiplex cinemas and what children possibly watch with their parents should not be neglected, even if considered to be of low educational value or of no value at all. In the latter case it is even more important to discuss and explain the content. What is more, a short look at the New Horizons repertoire of films for young children shows that its core consists of North European films, which come from such countries as Finland, Sweden, etc. What are the reasons for excluding other cinematographies? It is difficult to judge. What can be noticed and stays undoubfull is a predilection for arthouse cinema. The New Horizons educational projects seem to stick to the 
stereotypical conviction that there is a distinction between arthouse, artistic cinema representing high culture and worthy of interest, and entertaining, mainstream cinema that is of no educational use.

Just like children, education in Poland requires constant effort and care. Early childhood film and media education in particular is very demanding in this respect. That is why we should approach it seriously and professionally instead of avoiding problems, introducing illusory and partial solutions or creating prejudices and stereotypes. The obstacles that are yet to be overcome might appear daunting, but the process of improvement must start immediately if we do not want the next generation of children to be deprived of tools essential for efficiently navigating their way through modern societies. The New Horizons Association's numerous attempts to change the situation are inspiring and point to solutions that need to be explored.

\section{Bibliography:}

A Framework for Film Education (2015), http://www.koalicjafilmowa.pl/admin/reports/\%20bfia-framework-for-film-education-brochure-2015-06-12.pdf (access: 20.08.2017).

Depta, H. (1975). Film i wychowanie. Warszawa: Wydawnictwa Szkolne i Pedagogiczne.

Dzieciakinahoryzoncie.pl. http://dzieciakinahoryzoncie.pl/kino-dzieci-pro/ (access: 03.10.2017).

Godzic, W., et al. (2000). Raport o stanie edukacji medialnej w Polsce.

Godzic, W., Rudzińska, L., Kowalewska, M. (2015). Świat, który potrzebuje edukacji medialnej. Poznanie, terapia, wyzwanie, [in:] M. Federowicz, S. Ratajski (eds.), O potrzebie edukacji medialnej $w$ Polsce. Warszawa: Polish National Committee for Unesco, The National Broadcasting Council.

Grawon-Jaksik, A., Materska-Samek, M. (2016). Czy kinematografia kręci się wokót dzieci? Kondycja kinematografii dla dzieci i analiza uwarunkowań edukacji filmowej dzieci do 12 roku życia. Kraków: Fundacja Rozwoju Kina.

Huk, T. (2013). Media jako czynnik wspierający rozwój dziecka w wieku przedszkolnym. www. ktime.up.krakow.pl/symp2013/referaty_2013_10/huk.pdf (access: 10.03.2017).

Journal of Laws of 2014, item 803. Rozporzadzenie Ministra Edukacji Narodowej z dnia 30 maja 2014 zmieniajacym rozporzadzenie w sprawie podstawy programowej wychowania przedszkolnego oraz ksztatcenia ogólnego w poszczególnych typach szkót [Decree of the Minister of National

Education from 30 May 2014 amending the decree on the Core Curriculum for early childhood education and general education in all school types]. https://www.librus.pl/wp-content/ uploads/2014/10/D20140803.pdf (access: 20.08.2017).

Kinonh.pl. http://www.kinonh.pl/artykul.do?id=1519 (access: 03.10.2017).

Kosiński, D., Katafiasz, O., Marszałek, A. (2008). Standardy edukacji filmowej i teatralnej, [in:] A. Białkowski (ed.), Standardy edukacji kulturalnej: materiaty do konsultacji środowiskowej. Warszawa: Fundacja Polskiej Rady Muzycznej.

Kotarba-Kańczugowska, M. (2011). "Kilka uwag o wychowaniu przedszkolnym w Polsce na europejskim tle porównawczym.” Teraźniejszość-Cztowiek-Edukacja, 2 (54).

\section{4}


Kruszewska, A. (2013). Mass media i edukacja, [in:] Aktuálne otázky prírodovedno-technických predmetov a prierezových tém v primárnej edukácii. ONLINE KONFERENCIA 23-25.10.2013, Table 2. https://www.pulib.sk/web/kniznica/elpub/dokument/Kancir1/subor/Kruszewska.pdf (access: 03.10.2017).

Look again!' A teaching guide to using film and television with three- to eleven-year-olds (2003). London: BFI Education. http://www.bfi.org.uk/sites/bfi.org.uk/files/downloads/bfi-educationlook-again-teaching-guide-to-film-and-tv-2013-03.pdf (access: 22.08. 2017)

Men.gov.pl (2016). Wychowanie przedszkolne w Polsce. February 16. https://men.gov.pl/zycieszkoly/wychowanie-przedszkolne/przedszkola/wychowanie-przedszkolne-w-polsce.html (access: 10.03.2017).

Ofcom.org.uk (2014). Children and Parents: Media Use and Attitude Report. October. https://www.ofcom.org.uk/_data/assets/pdf_file/0027/76266/childrens_2014_report. pdf?lang=default (access: 03.10.2017.).

Smołalski, A. (2013). "Recenzja czasopisma Nowe Horyzonty Edukacji." Forum Oświatowe 1(48), 161-163. Retrieved from: http://forumoswiatowe.pl/index.php/czasopismo/article/ view/89 (access: 22.08.2017)

Suska Lidia, Projekt edukacji filmowej w ksztattowaniu postaw proekologicznych dzieci w wieku przedszkolnym (Project for Film Education in Shaping Pro-ecological Attitudes Among Preschool Children).www.przedszkola.edu.pl/_publikacje06/Artykul_o_edukacji_filmowej.doc (access: 22.08.2017).

Wróblewka, A. (2014). Sita przymusu a sita talentu, [in:] J. Armata, A. Wróblewska (eds.), Polski film dla dzieci i mtodzieży. Warszawa: Fundacja "Kino".

\section{Summary}

Film and media education in the case of preschool-age-children is a particularly complicated matter. There are many different factors, including the question of methodology, challenges which stem from the learning abilities and skills of young children that should be discussed. The article on the one hand tries to indicate the main obstacle that preschool audiovisual education in Poland deals with. But on the other hand it presents and describes as a case study the New Horizons Association projects dedicated to children age 3-7. As the New Horizons are a nongovernmental organisation, the kind of solution they propose does not solve all the problems and is limited and restricted. In the final part of the article I critically try to refer to, what is still for many, an exceptional proposition.

Keywords: film literacy, film education 